\title{
Formation of readiness for professional mobility in senior high school students
}

\author{
Michail Voropaev ${ }^{1 *}$ and Vladlen Sambur ${ }^{2}$ \\ ${ }^{1}$ Moscow City University, Department of Pedagogics, Moscow, Russia \\ ${ }^{2}$ Lyceum No.7 named after Ulanov, Khimki, Russia
}

\begin{abstract}
The prerequisites for the study are modern career concepts and the concept of preparing a person for the successful construction of a career path. The modern sphere of economic relations and the labor market are very changeable and dynamic. The structure and content of professions are changing quickly, which requires constant training and readiness from the individual to change professional roles. Therefore, the formation of readiness for professional mobility is an important research issue. However, the generally accepted position is that the formation of readiness for professional mobility among students should begin at a university or college. The purpose of the study is to test the assumption that the readiness for professional mobility can be formed in senior high school students by combining traditional and game forms of education. The experiment described used a three-week course based on traditional and active teaching methods and a complex multistep business game. The research methods included: the adapted test of "Career Anchors" by Edgar H. Schein, "Methodology for Diagnostics of Reflexivity" by A.V. Karpov and V.V. Ponomareva, the test "Study of Volitional Self-regulation" by A.V. Zverkov and E.V. Eydman, "Temperament Structure Questionnaire" by V.M. Rusalov, and the test "Communicative and Organizational Skills" by V.V. Siniavskii and V.A. Fedorishin. The results of the study showed a statistically significant positive change in the controlled parameters. In general, the conclusion about the promising nature of this direction of training can be considered partially confirmed. For a more confident conclusion, studies on larger samples are required.
\end{abstract} Keywords: readiness for professional mobility, game educational programs, education of senior high school students.

\section{Introduction}

Decades ago, the ideal professional career involved the successive ascent of an employee from one job level to another. The modern sphere of labor relations, without canceling careers in stable institutional environments, presupposes an employee's readiness for an unexpected change in the line of professional development. In sociology, there is an extensive list of concepts that characterize this path: "course", "pathway", "learning career", "life course", "school to work/life transition", "trajectory" [1-5].

\footnotetext{
*Corresponding author: voropmv@gmail.com
} 
Researchers use various theoretical constructs for analysis, depending on the choice of which main focus of the research changes: these are "decision points" that determine the life path $[4,6]$, the "topology" of the life trajectory, the sequence of stages of their living, the life trajectory as the relationship of collective and individual reality $[7,8,3]$, income received, powers of authority, working conditions [8-11], gender differences [12] etc.

The study of the factors destabilizing professional trajectories is not an exclusive feature of modern research. E.A. Klimov [13] singled out the stages of professionalization, the transition between which is often problematic. In the approach of E.F. Zeer [14], psychological crises are also distinguished, which the researcher divides into normative and non-normative.

All pedagogical works, setting the task of studying the formation of professional mobility, offer methods aimed at developing such student qualities as flexibility, liability, and ability to adapt to a changing professional and life situation $[15,16]$. However, usually, such a task is posed at the stage of a student receiving a higher or secondary vocational education.

We believe that for a person to build a successful professional career in the face of uncertainty of the future and the risk of repeated professional changes, it is necessary to form it in adolescents. The student needs to form an idea of the life path, which assumes that the future can bring multiple changes in the profession.

Based on the approaches outlined in the works of S.V. Nuzhnova and L.M. Mitina, we define readiness for professional mobility as a set of psychological qualities and social skills of a person, which provide an opportunity for effective management of their professional development in the context of a change of profession or specialty. We include the following in the content of this phenomenon: a semantic characteristic of a person's life plan, which implies a positive attitude towards the options of repeated professional changes, selfregulation skills, communication, resistance to stress and emotional stability, mastery of the primary methods of analyzing a professional situation, introspection, and designing professional development.

The hypothesis of our study is the assumption that the readiness for professional mobility can be formed in senior high school students through a combination of a special educational program and the organization of their experience of changing the professional field in a quasiprofessional activity.

\section{Methods}

By the beginning of the experimental stage, all subjects (students of the senior grades of two schools: Lyceum No.7 and Gymnasium No.16, Khimki, Moscow Region, Russia) had voluntarily undergone a preprofessional training program; all of them chose a circle, club, studio, elective, etc. and studied there for several months.

An experimental training program, implemented in the form of a single game form, was used as an independent variable in our study. Its essence boiled down to the following. All subjects were asked to temporarily change their professional direction (which was realized as a circle or an elective), choosing the one that the subject had not previously considered preferable and even possible.

The game had a clear time structure; it highlighted the stages of reactualizing the goal, collecting information about the situation on the "labor market", informing "potential employers" about oneself, passing the selection and assessment procedures, making a career decision, and adapting to a new place of work or study.

At the first stage, the students had to formulate the boundaries of admissibility and options for achieving their main life goals and correlate them with their capabilities and professional choice. The next game stage was the collection of information about the situation on the labor market (the "labor market" was imitated in the gaming space through the choice of various 
circles, electives, etc.). The player had to provide in the form of a presentation the results of the collection and analysis of information about a specific circle (elective), where they would like to go. In the course of subsequent stages, the player prepared a resume about them and was interviewed.

Throughout the game, each senior high school student found themself both in the role of a beginner, who had just adapted to a new activity, and in the role of a mentor (master), who had already completed the adaptation period. Each week of classes ended with a collective reflection, in which two students ("Beginner" and "Master") and a teacher-moderator took part.

The dependent variable - the level of formation of readiness for professional mobility was assessed according to the indicators obtained based on the following diagnostic methods: the "Career orientations" test by A.A. Zhdanovich [17] (adaptation of the "Career Anchors" test by Edgar H. Schein [18] (indicators - the scale "Stability of the Place of Work" (St-W), "Stability of the Place of Residence" (St-P), "Integration of Lifestyles" (Lf)) [19], "Methods for Diagnosing Reflexivity" (A.V. Karpov and V.V. Ponomareva) (the main indicator of the method used - (Refl)) [20], the "Study of Volitional Self-regulation" test by A.V. Zverkov and E.V. Eydman (indicator S_Reg) [21]), “Temperament Structure Questionnaire” by V.M. Rusalov (form of adolescents from 13 to 17 years old (D-OST) - plasticity scale (Liq)), the "Communicative and Organizational Skills" test by V.V. Siniavskii and V.A.Fedorishin (COS) (Lead indicator), and assessment of the quality of performance design work (Pr indicator) (Table 1).

Table 1. Correlation of criteria for the formation of professional mobility.

\begin{tabular}{|c|c|c|c|}
\hline $\mathbf{N}$ & $\begin{array}{c}\text { Criterion of } \\
\text { readiness for } \\
\text { professional } \\
\text { mobility }\end{array}$ & Indicators & Diagnostic tool \\
\hline 1 & Axiological & $\begin{array}{c}\text { Variable character of the } \\
\text { professional life plan }\end{array}$ & $\begin{array}{c}\text { Scales "Stability of the place of } \\
\text { Work", "Stability of the place of } \\
\text { Residence", the "Career orientations" } \\
\text { test by A.A. Zhdanovich [17] } \\
\text { (adaptation of the "Career Anchors" } \\
\text { test by Edgar H. Schein [18]) }\end{array}$ \\
\hline 2 & $\begin{array}{c}\text { "Methods for Diagnosing } \\
\text { Expressiveness of the } \\
\text { subject position }\end{array}$ & $\begin{array}{c}\text { Reflexivity" (A.V. Karpov and V.V. } \\
\text { Ponomareva), "Integration of } \\
\text { Lifestyles", the "Career Orientations" } \\
\text { test by A.A. Zhdanovich [17] }\end{array}$ \\
\hline 3 & $\begin{array}{c}\text { Personal and } \\
\text { component }\end{array}$ & $\begin{array}{c}\text { Self-regulation ability } \\
\text { regulation" test by A.V. Zverkov and } \\
\text { E.V. Eydman }\end{array}$ \\
\hline 5 & $\begin{array}{c}\text { Operational-activity } \\
\text { component }\end{array}$ & $\begin{array}{c}\text { Communication and } \\
\text { for professional mobility in } \\
\text { situations of job search, } \\
\text { choice, and adaptation to a } \\
\text { new place of work (study) }\end{array}$ & $\begin{array}{c}\text { "Communicative and Organizational } \\
\text { Skills" test by V.V. Siniavskii and } \\
\text { V.A. Fedorishin (COS) }\end{array}$ \\
\hline & & & Project work \\
\hline
\end{tabular}

Project work was a task that was carried out in a limited time and in which it was required to show mastery of the primary methods of analyzing the professional situation (including the labor market), introspection, and designing professional development. 
Several indicators were converted to the opposite (St-W, St-P). All these scales were normalized to a 100 -point scale for ease of interpretation and visualization.

\section{Results}

The study was carried out on a sample of 142 people: 68 of them were included in the experimental group and 74 - in the control group. The period of experimental work covered 2019-2020. The results are shown in Table 2.

Table 2. Average values of the main indicators of the formation of readiness for professional mobility and an assessment of their significance.

\begin{tabular}{|l|c|c|c|c|c|c|c|c|}
\hline \multirow{2}{*}{ Groups } & \multicolumn{7}{|c|}{ Average values of key indicators } \\
\cline { 2 - 9 } & St-W & St-P & Lf & Refl & S_Reg & Liq & Lead & Pr \\
\hline Control & 67.3 & 58.1 & 43.2 & 44.6 & 52.5 & 61.2 & 63.6 & 42.1 \\
\hline Experimental & 76.9 & 60.2 & 47.1 & 49.1 & 58.2 & 62.3 & 70.7 & 80.4 \\
\hline P $\leq *$ & 0.00 & Insignificant & 0.05 & 0.05 & 0.05 & Insignificant & 0.00 & 0.00 \\
\hline
\end{tabular}

$* \mathrm{P} \leq-$ confidential interval

Despite the significance of the differences, the changes in the criteria were different. The axiological indicator changed primarily due to changes in the value characteristics of a possible future. Senior high school students began to admit to a greater extent the possibility of probabilistic changes in their planning and its uncertainty. The realized program prompted a certain part of the subjects to revise their own position in planning their future, that is, the program created conditions for the growth of such an important quality as subjectivity. The growth of subjectivity was evidenced by the analysis of the results of a structured interview. In $34 \%$ of interviews, an actualization of the problem of choosing an option for personal and professional development and the role of the subject in this choice was observed (for comparison, at the initial stage of the experiment, $22 \%$ of the respondents had such reasoning). The ability for self-regulation, as well as communicative and organizational qualities, increased in the experimental groups, although significantly, but within 10-15 points of the scale dimension. Again, we believe that for a slightly more than half-year program, this is a very good result.

The operational-activity component showed the most significant increase. This is not surprising, since the sphere of practical skills is much more available for formation than deeper personal education. The overwhelming majority of the participants from the experimental group fully reproduced all the recommended elements and stages of actions from the situation of choosing a new profession. A significant part of this number demonstrated the qualities of subjectivity, i.e. not only offered the right solutions for a certain situation but also set their self-development as one of the main goals.

\section{Conclusion}

The results of our experimental work give certain grounds for the conclusion that our initial hypothesis has been confirmed. Firstly, the readiness for professional mobility can be formed from the age of 15-17 and, secondly, a relatively compact educational program in combination with a complex game can provide noticeable positive changes in the level of development of this quality.

The results presented in the study are initial and further studies on larger samples are required. 


\section{References}

1. L. Faure, P. Vendramin, D. Schurmans, Internet Policy Review, 9(2) (2020). https://doi.org/10.14763/2020.2.1475

2. M. Bloomer, P. Hodkinson, British Educational Research Journal, 26(5) (2000). https://doi.org/10.1080/01411920020007805

3. P. Benz, F. Bühlmann, A. Mach, Higher Education, (2020). https://doi.org/10.1007/s10734-020-00590-7

4. G.H. Elder, The life course, in The encyclopedia of sociology, 2nd ed., 3, 1614-1622 (MacMillan, New York, 2000)

5. J. Liu, Z. Yin, W. Lyu, S. Lin, Sustainability, 11(24), 6925 (2019). https://doi.org/10.3390/su11246925

6. M.D. Baranowski, Journal of Marriage and the Family, 62(3) (2000). Accessed on: December 16, 2020. [Online]. Available: https://www.questia.com/library/journal/1P358647129/children-of-the-great-depression

7. P. Bourdieu, Habitus and Field: General Sociology, 2(1982-1983) (Polity Press, Cambridge, 2020)

8. R. Fevre, I. Guimarães, W. Zhao, Review of Education, 8(3), 693-726 (2020). https://doi.org/10.1002/rev3.3204

9. C. Maiorca, et al., International Journal of Science and Mathematics Education, 19, 45-64 (2021). https://doi.org/10.1007/s10763-019-10038-9

10. R. Mohd Rasdi, S. Ahrari, Plos One, 15 (8), e0237838 (2020). https://doi.org/10.1371/journal.pone.0237838

11. B. Merrill, F. Finnegan, J. O’Neill, S. Revers, Studies in Higher Education, 45(1), 1-13 (2019). https://doi.org/10.1080/03075079.2019.1570492

12. M. Lee, J.T. Mortimer, J Youth Adolescence (2020). https://doi.org/10.1007/s10964020-01263-5.

13. E.A. Klimov, Psikhologiya professionala [Psychology of a Professional] (Institute of Practical Psychology, Voronezh, 1996)

14. E.F. Zeer, Psikhologiya professii [Psychology of Profession] (Delovaya kniga, Ekaterinburg, 2003). Accessed on: December 16, 2020. [Online]. Available: https://kirovipk.ru/sites/default/files/dokumenty/zeer_e.f._psihologiya_professiy.pdf

15. L.M. Mitina, Psikhologiia lichnostno-professionalnogo razvitiia subiektov obrazovaniia [Psychology of Personal and Professional Development of Subjects of Education] (Nestor-Istoriya, Saint-Petersburg, 2014). Accessed on: December 16, 2020. [Online]. Available:

https://www.pirao.ru/images/workers/MitinaLM/psikhologiya-razvitiya.pdf

16. S.V. Nuzhnova, Vestnik sovremennykh issledovanii, 2.1(29), 67-71 (2019)

17. A.A. Zhdanovich, Psychologicheskiy Zhurnal, 4(16), 4-22 (2007). Accessed on: December 16, 2020. [Online]. Available: http://media.miu.by/files/store/items/pj/16/pj_16_2007_1.pdf

18. E.H. Schein, J. van Maanen, Career Anchors: The Changing Nature of Careers Self Assessment (Wiley, New Jersey, 2013)

19. E.A. Koltsova, Organizatsionnaya Psikologiya, 2(4), 59-67 (2012). Accessed on: December 16, 2020. [Online]. Available: https://orgpsyjournal.hse.ru/data/2013/02/18/1306938504/OrgPsy_20124_Koltsova_59-67.pdf 
20. A.V. Karpov, Psikhologicheskii Zhurnal, 24(5), 45-57 ( 2003)

21. T.I. Pashukova, A.I. Dopira, G.V. Diakonov, Psikhologicheskie issledovaniia [Psychological Research] (Institute of Practical Psychology Publishing House, Moscow, 1996). Accessed on: December 16, 2020. [Online]. Available:

http://elcat.pnpu.edu.ua/docs/практикум.pdf 